\title{
Wychowanie do zrównoważonego rozwoju w szkole podstawowej
}

Rozwój cywilizacji niewątpliwie ułatwia życie człowiekowi, zmniejsza jego uzależnienie od wpływów przyrody, ale jednocześnie uzależnia od wytworów techniki, co pociąga za sobą nieuchronne naruszenie równowagi przyrodniczej i już dzisiaj jest przyczyną globalnych zmian klimatycznych, efektu cieplarnianego, rozrzedzenia osłony ozonowej, zanieczyszczeń wody, gleby i powietrza. Edukacja środowiskowa nie zmieni tych tendencji, ale ukształtuje świadomość uczniów o ścisłej zależności człowieka od środowiska przyrodniczego. Jej zadaniem jest również wprowadzenie młodzieży w świat niezwykłych przeżyć emocjonalnych i estetycznych związanych z przebywaniem w środowisku oraz wykształcenie umiejętności świadomego włączenia się w dzieło ochrony i kształtowania środowiska (Kąkol, 2002).

Szkoła jako jedna z instytucji edukacyjnych, winna wyposażyć wychowanków w określoną wiedzę o środowisku przyrodniczym, kształtować odpowiedzialność za swoje czyny w stosunku do otoczenia i samego siebie, uświadomić zagrożenia, jakie niesie współczesna cywilizacja, wyposażyć w umiejętności prawidłowego gospodarowania zasobami przyrody i współtrwania z nią. Cele nauczania zintegrowanego i założenia teoretyczne edukacji środowiskowej są możliwe do osiągnięcia, gdy dziecko w toku nauki będzie miało stworzoną możliwość twórczego odkrywania, poznawania i rozumienia zasad funkcjonowania rzeczywistości oraz będzie miało możliwość praktycznego reagowania i odpowiadania na problemy poznawczej rzeczywistości. W innym przypadku, jak pisze Zioło (2002) wiedza środowiskowa stanie się jedynie zbiorem luźnych faktów i nazw dowolnie wykorzystywanych w innych obszarach edukacji (w praktyce szkolnej treści środowiskowe wykorzystywane są często jako ilustracja innych zamierzeń dydaktycznych) i jedynie materiałem ilustracyjnym dla innych obszarów edukacji. Bardzo często treści środowiskowe stanowią wątek merytoryczny do inicjowania zajęć z innych obszarów edukacji. Wokół nich bowiem można integrować edukację matematyczną, polonistyczną czy też inną. Ogniskowanie pracy dziecka wokół jednostek tematycznych wyzwala w naturalny sposób ciekawość i zainteresowanie przedmiotem poznania, holistyczną interpretację poznawczych tematów, zjawisk oraz zapewnia wielostronny rozwój osobowości. 
Nowe zadania i cele edukacji dla środowiska Czaja i Bajon (2001), scharakteryzowali następująco:

- przygotowanie do „twórczego bycia” i nauczenie odpowiedzialności związanej z poczuciem sprawstwa,

— uświadamianie doznań oraz przeżyć dostarczanych przez otoczenie i świat,

- odniesienie tychże doświadczeń, doznań i przeżyć do systemu wartości,

- wszechstronny rozwój człowieka -fizyczny, intelektualny, zmysłowy, emocjonalny.

Budowanie świadomości ekologicznej poprzez edukację ma oznaczać, zdaniem autorów, nie tylko wiedzę i przekonania, ale również doznania i przeżycia - co jest szczególnym wyzwaniem dla wolnych inicjatyw edukacyjnych o różnorodnych historycznie i kulturowo korzeniach, ale tworzących alternatywy wzorów i sposobów życia. Nowe, alternatywne spojrzenie na edukację ekologiczną to otwarcie na otoczenie, postęp i twórczość, to pobudzanie do samodzielnej aktywności poznawczej, kształtowanie i rozwój zainteresowań, zaspokajanie wszechstronnych potrzeb intelektualnych, wdrażanie samokształcenia, stymulowanie współdziałania.

Zgodnie z wymogami współczesnej dydaktyki (Dylak, 1997), na prawidłowe planowanie pracy dydaktyczno-wychowawczej z zakresu edukacji środowiskowej, realizowanej w ramach zintegrowanej edukacji wczesnoszkolnej składać się powinna pięciofazowa procedura postępowania nauczyciela, obejmująca formułowanie celów, dobór odpowiednich działań, czynności uczniów, opracowanie zadań, które najlepiej uruchomią czynności uczniów, konieczne do realizacji celów, kontrolę stopnia realizacji założonych celów, czyli określenie wskaźników osiągania założonych celów, ewaluację, czyli ocenę ze względu na ogół zmian, jakie zaszły w umysłach uczniów, opinie uczących się i wykorzystanie środków. W koncepcji programowej edukacji szkolnej ucznia klas początkowych ogólne cele kształcenia środowiskowego określone są następująco: „Celem edukacji przyrodniczej jest systematyczne, coraz dogłębniejsze poznawanie przez dziecko i rozumienie przyrody w jej różnych aspektach i związkach przyczynowo-skutkowych i probabilistycznych. W poznawaniu przyrody obowiązuje PRAWDA" (Hanisz, 1998).

Aspekt poznawczy edukacji przyrodniczej obejmuje szereg kręgów zagadnieniowych, dotyczących treści przyrodniczych, geograficznych, społecznych, historycznych oraz związanych z higieną i bezpieczeństwem dziecka. Poznawana przez dziecko wiedza dotyczy znajomości podstawowych gatunków roślin i zwierząt jego najbliższego otoczenia, ich głównych cech zewnętrznych i funkcji oraz wybranych środowisk społeczno-przyrodniczych. Jego otoczenia naturalnego i w różny sposób przekształconych przez człowieka, takich jak: szkoła, dom rodzinny, osiedle, miejscowość, najbliższa okolica, wybrane miasta Polski, ogród, sad, pole uprawne, łąka, gospodarstwo hodowlane, las, środowisko wodne. 
Treści te program nauczania ujmuje w określone kręgi tematyczne, uwzględniające omawiane zagadnienia dostosowane do możliwości percepcyjnych dziecka $\mathrm{w}$ wieku wczesnoszkolnym.

Kategoria celów kształcących przewiduje opanowanie przez dziecko określonych umiejętności umysłowych, tj.: umiejętność analizy i syntezy, porównywania, klasyfikowania, abstrahowania i uogólniania, wnioskowania, wykrywania zależności przyczynowo-skutkowych oraz związków czasowych, przestrzennych i funkcyjnych, a także szereg umiejętności przedmiotowych związanych ściśle z poznawanymi treściami.

Termin edukacja środowiskowa powszechnie używany jest w sposób niejednoznaczny. W licznych opracowaniach zauważa się synonimy takie jak edukacja przyrodnicza, edukacja ekologiczna, edukacja geograficzna. Niewątpliwie jest to pojęcie szerokie, będące przedmiotem poznania wielu dyscyplin naukowych (geografii, biologii, chemii, fizyki, matematyki a nawet dyscyplin humanistycznych) intuicyjnie utożsamianych z przyrodą, odnoszące się do rzeczywistości czerpanej z natury.

Zioło (2002) zauważa, że w literaturze naukowej (przyrodniczej, humanistycznej i dydaktycznej) funkcjonują różne terminy pojęcia środowiska, ujmujące je samodzielnie lub też z określonym przymiotnikiem, jako np.; środowisko przyrodnicze, geograficzne, społeczne, naturalne, ekonomiczne, kulturowe, społeczne czy inne. Na poziomie kształcenia wczesnoszkolnego, zgodnie z aktualnymi wymogami programowymi, zakres treściowy przedmiotu edukacji środowiskowej, jak pisze autorka, jest zawężony do wybranych aspektów rzeczywistości. Odnosi się głównie do jej aspektów przyrodniczych i społecznych. Tak więc rozpatrywane jest w ujęciu ekologicznym, fenologicznym i sozologicznym.

Sawicki (1997) traktuje środowisko jako całość tego, co otacza człowieka, w czym człowiek tkwi, co na niego oddziałuje i na co on sam działa. Człowiek, podobnie jak każdy żywy organizm, powiązany jest ze środowiskiem swoimi potrzebami. Ze środowiska czerpie konieczne do życia substancje, czasami konkuruje z innymi organizmami o różne dobra środowiska (gusty, aspiracje). Potrzebuje też różnych więzi społecznych i kulturowych, chociażby po to, by zaspokoić swoje dążenia do dobra, piękna, prawdy. Miejsce człowieka w łańcuchu troficznym wynika w znacznym stopniu z pozycji społeczno-ekonomicznej. W związku z powyższym, niszą człowieka jest nie tylko jego środowisko przyrodnicze i inni ludzie, ale też sztuczne środowisko wytworzone przez niego samego, czyli wszystkie wytwory materialne jego kultury, a także wytwory myśli i wyobraźni. Tak rozumiana nisza ekologiczna powinna podlegać modyfikowaniu, gdyż w przeciwnym wypadku może nastąpić nieprzystosowanie. Tu właśnie ogromnego znaczenia nabiera edukacja środowiskowa, prowadzona od pierwszego etapu kształcenia. Naturalnym jest, że człowiek, tak w sensie ludzkości jak i w znaczeniu indywidualnym, tworząc swoje sztuczne środowisko kulturowe 
i modyfikując środowisko naturalne, pragnie osiągnąć korzystne dla siebie efekty. Zmiana środowiska korzystna w sensie indywidualnym lub grupowym, może mieć skutki uboczne. Nie kształtowana świadomość ekologiczna i proekologiczna, słaba wiedza na temat praw przyrody już w wieku szkolnym spowoduje, że zgodnie z prawami ewolucji, wszelkie negatywne zmiany w zachowaniach przyszłych pokoleń będą się utrwalały.

Definicje środowiska prezentowane przez różnych autorów nie odbiegają od opisanego wyżej toku myślowego, np.: środowisko w zapisach Międzynarodowej Karty Ochrony Środowiska (Cichy, 1996) jest to układ stosunków przyrodniczych, ekonomicznych i społecznych, w których żyje człowiek. Bratkowski (1979) traktuje je jako zbiór czynników oddziałujących na podmiot środowiska.

W takim rozumieniu definicji środowiska Zioło (2002) zauważa, że na to pojęcie składają się trzy elementy: podmiot środowiska, obiekt poddany działaniu pewnego procesu (oddziaływanie czynników) oraz przedmiot środowiska, czyli zbiór czynników skierowanych na podmiot. Tak więc edukacja środowiskowa nie może być skierowana tylko na aspekt przyrodniczy, obejmuje ona swym zasięgiem wszystkie dziedziny wiedzy, we wszystkich trzech wymiarach pracy szkoły: gnoseologicznym, aksjologicznym i prakseologicznym.

Efektywność procesu edukacyjnego w zakresie edukacji środowiskowej (pozostałych również) wiąże się m.in. z potrzebą strukturalnego ujęcia treści programowych, po to, by w umyśle dziecka budowała się kategoria poznawcza rzeczywistości. Owa struktura (łac. structura - układ, uporządkowanie) to, w odniesieniu do treści programowych, strukturyzacja, czyli czynność związana z kształtowaniem treści dydaktycznych (Okoń, 1987) tj. takie porządkowanie materiału, aby w nim wyodrębnić jakieś układy, a w nich elementy i związki między nimi. Uwzględnienie z kolei funkcji tych układów służy ustosunkowywaniu układów względem siebie i tworzeniu ich hierarchii. Służy ona hierarchizowaniu transmitowanej wiedzy w umyśle dziecka, zapewnia większą jej operatywność i trwałość. Ma również duże znaczenie w kształtowaniu kompetencji nauczycielskich do edukowania środowiskowego, gdyż zapewnia poprawne planowanie i projektowanie przebiegu procesu dydaktyczno-wychowawczego, jak też wspomaga i ukierunkowuje przewidywanie różnych sytuacji, które mogą mieć miejsce podczas lekcji w klasie szkolnej.

Znaczenie środowiska dla współczesnego człowieka jest ogromne i dlatego też cele kształcenia przyrodniczego powinny być realizowane na wszystkich szczeblach edukacji szkolnej, począwszy od etapu edukacji przedszkolnej i wczesnoszkolnej. Kształcenie środowiskowe winno uwzględniać różnorodne aspekty relacji człowieka ze środowiskiem, w ujęciu globalnym, regionalnym i lokalnym. Wskazywać możliwości i kierunki prośrodowiskowej działalności społeczno-ekonomicznej i kulturowej człowieka. Kształtować kreatywne postawy względem przyrody (Jarzyńska, 2004). 
Ze względu na ogólnorozwojowe wartości przedmiotu, jakim jest edukacja środowiskowa, przy prawidłowym jej przebiegu jest możliwy wszechstronny rozwój dziecka: jego percepcji słuchowej, określonych umiejętności intelektualnych, aktywności twórczej i emocjonalnej, wrażliwości estetycznej i społecznej oraz umiejętności praktycznych. Jesteśmy krajem Wspólnoty Europejskiej, obliguje to nas do wprowadzania prawa unijnego. Najważniejszym międzynarodowym dokumentem dotyczącym edukacji ekologicznej jest opracowana w ramach IEEP Międzynarodowa Strategia Edukacji Środowiskowej (1990). Stała się podstawą dla kolejnych dokumentów dotyczących edukacji ekologicznej, w tym dokumentów Unii Europejskiej. Z dokumentów tych wynika, że edukacja ekologiczna w polityce ekologicznej UE ma obok informacji znaczenie priorytetowe.

Obecnie w polityce środowiskowej Unii Europejskiej obowiązuje VI Program działań w dziedzinie środowiska naturalnego „Środowisko 2010: Nasza przyszłość zależy od naszego wyboru" na lata 2001-2010. Komisja Europejska zaplanowała w nim jako priorytetowe przeciwdziałanie zmianom klimatycznym, ochronę bioróżnorodności, oszczędne wykorzystanie zasobów naturalnych połączone z rozwojem gospodarki odpadami oraz dbałość o wpływ środowiska na zdrowie (surowsze normy). Po raz kolejny akcentuje się fundamentalną rolę edukacji ekologicznej. Jej realizowanie zapewni wdrożenie prawa ekologicznego, bliską współpracę między różnymi sektorami w celu znalezienia najlepszych rozwiązań, usprawni przepływ informacji oraz podkreśla równocześnie fundamentalną rolę szkół i nauczycieli we wdrażaniu i rozwoju tej edukacji.

Znaczenie środowiska dla współczesnego człowieka jest ogromne i dlatego też cele kształcenia przyrodniczego powinny być realizowane na wszystkich szczeblach edukacji szkolnej, począwszy od etapu edukacji przedszkolnej i wczesnoszkolnej. Kształcenie środowiskowe winno uwzględniać różnorodne aspekty relacji człowieka ze środowiskiem, w ujęciu globalnym, regionalnym i lokalnym. Wskazywać możliwości i kierunki prośrodowiskowej działalności społeczno-ekonomicznej i kulturowej człowieka. Kształtować kreatywne postawy względem przyrody (Jarzyńska, 2004).

W kontekście zrównoważonego rozwoju chciałbym zaprezentować funkcjonowanie Publicznej Szkoły Podstawowej nr 6 w Nowej Soli, w której zarządzam od 1991r.

Wszechstronny, harmonijny rozwój dziecka jest głównym celem pracy szkoły i wszystkie działania podejmowane $w$ tej placówce muszą służyć jego realizacji. Tak napisałem pięć lat temu (2003 r.), tworząc konkursową koncepcję pracy Szkoły Podstawowej nr 6 w Nowej Soli. Dzisiaj z pełną konsekwencją powtarzam te słowa, gdyż uważam, że nie straciły swojej aktualności. Chcę je jednak uzupełnić o nowe sformułowanie: aby cel ten osiagnąć, konieczna jest zgodna i efektywna wspótpraca wszystkich nauczycieli, wychowawców oraz ludzi $i$ instytucji wspomagajacych szkołę. 
Misją Publicznej Szkoły Podstawowej nr 6 w Nowej Soli jest:

- Pomóc osiągnąć sukces każdemu uczniowi.

- Jesteśmy szkołą dla uczniów, rodziców i lokalnej społeczności.

- Nasza szkoła jest miejscem, gdzie stwarza się warunki do nauki wszystkim dzieciom.

- Motywujemy uczniów do rzetelnej i systematycznej pracy.

- Przekazujemy wiedzę i umiejętności pozwalające wszystkim uczniom na kontynuowanie edukacji na miarę ich możliwości.

- Zaznajamiamy uczniów z normami społecznymi oraz wspomagamy rodziców $\mathrm{w}$ procesie wychowania.

- Uczymy przestrzegania norm społecznych, szacunku wobec innych oraz wzajemnej tolerancji.

- Pielęgnujemy tradycję szkolną, regionalną i narodową.

- Nasi uczniowie czują się obywatelami Europy.

- Podążamy za wymogami współczesnej cywilizacji, mając na uwadze wielokierunkowy rozwój ucznia.

Tę politykę realizujemy w oparciu o naszą wizję, czyli naszych marzeniach o tym, jacy absolwenci opuszczają Naszą Szkołę.

Wizja Publicznej Szkoły Podstawowej nr 6 w Nowej Soli.

Absolwent Naszej Szkoły:

- Posiada wiedzę i umiejętności pozwalające mu na kontynuowanie edukacji na miarę swoich możliwości.

- Rozpoznaje, rozumie, akceptuje i respektuje uniwersalne wartości: prawdę, dobro i piękno.

- Umie żyć w społeczeństwie, potrafi współdziałać i porozumiewać się z innymi ludźmi.

- Jest patriotą i Europejczykiem.

- Potrafi rozwiązywać różnorodne problemy we własnym działaniu, radzi sobie $\mathrm{z}$ trudnościami.

Wszystkie wspomniane wyżej materiały są wykorzystywane przy opracowywaniu dokumentów, procedur i trybów wewnątrzszkolnych. W ich tworzeniu biorą udział także rodzice i uczniowie. 


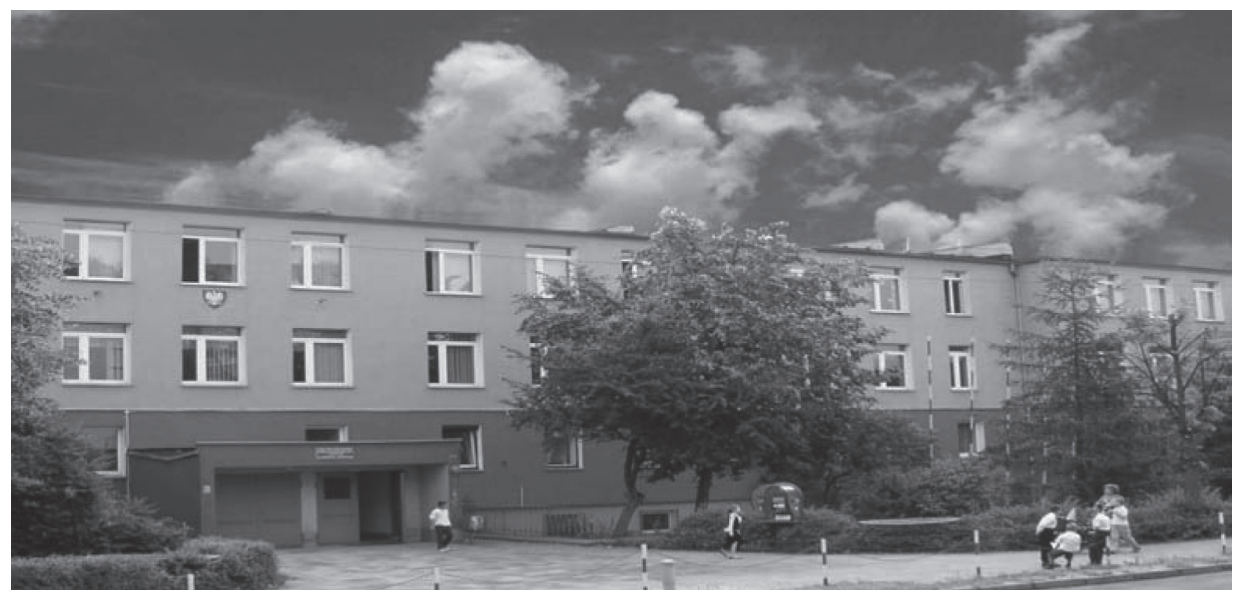

PSP-6 w Nowej Soli

Na zdjęciu widoczne są tylko niektóre, najważniejsze elementy misternej konstrukcji szkoły.

Tak więc...

Aby budynek był trwały i mocny, konieczne są w nim SOLIDNE FUNDAMENTY, czyli:

- zasady dobrego wychowania wyniesione $\mathrm{z}$ domu rodzinnego,

- solidne podstawy wiedzy uzyskane w szkole podstawowej,

- dokładne rozpoznanie środowisk, z których pochodzą uczniowie,

- dążenie do modelu absolwenta,

- określona misja i wizja szkoły na podstawie oczekiwań jej klientów,

- stworzenie wieloletniego planu rozwoju szkoły wraz ze strategią jego realizacji.

\section{Parter budowli tworzą zagadnienia wychowawcze}

Założeniem reformy systemu oświaty jest nadanie wychowaniu w szkole wysokiej rangi. Jest to bardzo wyraźnie widoczne, zarówno w ustawie o systemie oświaty, jak i w zadaniach ogólnych szkoły, wyrażonych w podstawie programowej. Praca wychowawcza szkoły opiera się na wytycznych Wizji i Misji szkoły. Na ich podstawie zmodyfikowane zostały zapisy w Statucie Szkoły. Wdrożono: Szkolny Program Wychowawczy oraz współpracujący z nim Szkolny Program Profilaktyki, w których określono zasady bezpieczeństwa i opieki uczniów w szkole i na terenie do niej przynależnym. Program wychowawczy wspomaga rozwój ucznia. Zawiera on zadania długofalowe, powtarzające się i stale doskonalone oraz krótkofalowe, obejmujące określony czas, wynikające z potrzeby, ujawnione podczas mierzenia jakości pracy, bądź z obchodzonych rocznic czy ważnych uroczystości. 
Szkoła, którą kieruję, kształtuje osobowość uczniów, a także wspomaga rodziców w ich funkcji wychowawczej poprzez:

- stworzenie płaszczyzny współpracy polegającej na dialogu i budowaniu wzajemnego zaufania w relacji uczeń - rodzic - nauczyciel (wychowawca);

- dbanie o drożność kanałów komunikacji społecznej;

- wspólne z rodzicami dokonywanie ewaluacji Szkolnego Programu Wychowawczego;

- zaproponowanie nowej formy spotkań z rodzicami:

- z udziałem uczniów, którzy mają możliwość zaprezentowania swoich nowych umiejętności przed rodzicami; także poza szkołą,

- wspólne rozwiązywanie problemów wychowawczych (np. zajęcia warsztatowe),

- zapraszanie specjalistów na spotkania i prelekcje w klasach, zgodnie z zapotrzebowaniem rodziców i uczniów,

- organizowanie wspólnych dla wszystkich chętnych rodziców spotkań tematycznych;

- zaproponowanie dzieciom jak najszerszego uczestnictwa w wydarzeniach kulturalnych;

- pomoc rodzinom niewydolnym wychowawczo:

- pomoc materialna dla dzieci, np.: bezpłatne obiady w szkole, zaopatrzenie w odzież sezonową i przybory szkolne - szukanie sponsorów,

- porady udzielane przez wychowawców, pedagoga i psychologa szkolnego, zajęcia socjoterapeutyczne z uczniami,

- ścisły kontakt $\mathrm{z}$ instytucjami wspomagającymi: sądem rodzinnym, kuratorem sądowym, policją, MOPS, CPR, PPP,

- konsekwentne egzekwowanie realizacji przez uczniów obowiązku szkolnego;

- realizacja Programu Profilaktyki Szkoły ze szczególnym uwzględnieniem przeciwdziałania uzależnieniom i bezpieczeństwa.

Współpraca z rodzicami, to nie tylko wspomaganie wychowawcze. To także propozycja współdziałania w znacznie szerszym zakresie w ramach Rady Rodziców. Zadania i kompetencje Rady Rodziców są, moim zdaniem, w tworzonym obecnie kształcie placówki oświatowej, koniecznością. Dobra, prężnie działająca Rada Rodziców wywiera bardzo korzystny wpływ na różnorodną działalność szkoły. Przykładem może być obecna Rada Rodziców PSP-6 w Nowej Soli.

Wychowanie - to także wdrażanie dzieci do udziału w życiu publicznym, które w szkole polega na działalności Samorządu Uczniowskiego. 


\section{Pierwsze piętro - dydaktyka}

Nasi uczniowie uczą się w oparciu o spójny szkolny zestaw programów nauczania. Programy zostały dostosowane do możliwości uczniów oraz do warunków bazy szkolnej. Uczniom słabym udzielana jest pomoc w ramach zajęć wyrównawczych, a wszyscy uczniowie mogą skorzystać z oferty zajęć pozalekcyjnych:

- bezpłatnych w ramach godzin do dyspozycji dyrektora oraz finansowanych $\mathrm{z}$ budżetu gminy.

Zajęcia pozalekcyjne są organizowane zgodnie z potrzebami i zainteresowaniami uczniów. Są to:

- koła przedmiotowe,

- koła zainteresowań,

- zajęcia sportowe i rekreacyjne.

Atrakcyjny plan nauczania motywuje uczniów do nauki, umożliwia nauczycielom pracę w różnych obszarach aktywności i zdolności uczniów. Obecnie szkoła posiada certyfikaty:

- od 2003 r. SZKOŁY Z KLASĄ (akcja Gazety Wyborczej),

- od 2006 r. SZKOŁY PROMUJĄCEJ ZDROWIE.

Szkoła prowadzi wymianę młodzieży:

- od 1991 r. trwa wymiana uczniów między College w Latronguiere z Francji,

- od 2004 r. została nawiązana współpraca ze szkołą w Niemczech „Grundschule Am See” z Senftenbergu.

Rok rocznie mamy laureatów i finalistów w wojewódzkich konkursach przedmiotowych. W sporcie sięgamy wyżyn ogólnopolskich i nie tylko:

- Wychowanek jednej z klas sportowych - Marcin Szulik wraz z reprezentacją Polski zdobył Mistrzostwo Europy Juniorów, był zdobywcą „złotej bramki” w finałowym meczu, później reprezentował Polskę na Mistrzostwach Świata $\mathrm{w}$ Japonii.

- Od 1996 r. działa zarejestrowany U.K.S. „Szóstka”. W szkole są także prowadzone przez nauczycieli wychowania fizycznego zajęcia rekreacyjno-sportowe dla wszystkich chętnych. Od 7 lat uczniowie naszej szkoły biorą aktywny udział w zawodach sportowych w cyklu” "Czwartki Lekkoatletyczne”.

- W Finale Ogólnopolskim w Warszawie, w roku szkolnym 2000/01 Grzegorz Kozioł w rzucie piłeczką palantową zajął $7 \mathrm{~m}$-ce; w roku 2002/03 ucz. Anna Tomasiewicz zajęła 11 m-ce w skoku w dal; w roku szkolnym 2005/06 ucz. Martyna Stuła w biegu na $800 \mathrm{~m}$ zajęła $10 \mathrm{~m}$-ce. W październiku $2006 \mathrm{r}$. w Łęknicy, w Finale Lubuskiej Olimpiady Młodzieży w biegach przełajowych zajęła $1 \mathrm{~m}$-ce.

Zasadniczy cel to dobre przygotowanie uczniów do sprawdzianów zewnętrznych, co otworzy im drogę do dalszego kształcenia. Pomogą nam w tym nauczy- 
ciele - egzaminatorzy OKE, których w szkole mamy coraz więcej (8). Obecnie tendencja rozwojowa szkoły na przestrzeni lat 2002 - 2008 osiąga wzrost postępu w zakresie osiągnięć szkoły - stan: bardzo wysoki.

\section{Drugie piętro - bezpieczeństwo i opieka}

Zgodnie z posłannictwem szkoły kształtować należy u uczniów właściwe postawy, rozwijać zdolność wydawania prawidłowych sądów, wprowadzać w dziedzictwo kultury wytworzonej przez przeszłe pokolenia, kształcić zmysł wartości, sprzyjać dyspozycjom do wzajemnego zrozumienia się, stwarzając przyjazne współżycie wśród wychowanków, różniących się charakterami i pochodzeniem. Zapisy statutowe umożliwią rodzicom realny wpływ na rozwiązania systemowe w szkole (poprzez statutowe uprawnienia Rady Rodziców). Obecnie występuje ścisła współpraca z rodzicami uczniów, wspólne organizowanie imprez i zabaw, konkursów i zawodów, festynów itp. Szkoła stanowi pewne centrum, w którego wysiłkach i osiągnięciach uczestniczą równocześnie rodziny, nauczyciele, różnego rodzaju organizacje rozwijające życie obywatelskie, kulturalne i religijne.

Wspólnie z Koordynatorem ds. bezpieczeństwa, integrujemy działania wszystkich podmiotów szkolnych (nauczycieli, uczniów, rodziców) oraz współpracujących ze środowiskiem w zakresie bezpieczeństwa. Do naszej szkoły uczęszcza 550 uczniów. $20 \%$ to uczniowie z poza obwodu szkoły. Wszyscy oni mają możliwość uczęszczania do świetlicy szkolnej. Zadaniem wychowawców świetlicy jest zapewnić im bezpieczeństwo i opiekę. Konieczne także jest zaproponowanie uczniom ciekawych form spędzania czasu w świetlicy:

A. Rozpoznanie zainteresowań i potrzeb uczniów uczęszczających do świetlicy oraz zaproponowanie im odpowiednich zajęć, np.:

- nauka tańca,

- zajęcia plastyczne,

- zajęcia sportowe,

- zajęcia terapeutyczne (profilaktyka).

B. Ekologia i regionalizm:

- praca na rzecz własnego środowiska i rodziny („drzewo dobrych uczynków"),

- „Osobliwości naszej miejscowości” - grupa dzieci prezentuje w różnych formach swoją miejscowość,

- szkolny konkurs wiedzy o mieście - zakończenie i ukoronowanie serii prezentacji.

C. Zdrowa szkoła:

- realizację ścieżki prozdrowotnej,

- propagowanie zdrowego stylu życia. 
Bardzo ważnym miejscem w działalności dydaktycznej szkoły jest biblioteka szkolna.

\section{Najwyższy poziom - dach}

Współpraca ze środowiskiem lokalnym:

- współpraca z organem prowadzącym - realizacja zaleceń i wniosków przewidzianych prawem;

- ścisła współpraca z instytucjami kultury i oświaty w mieście, gminie i powiecie;

- współpraca ze związkami zawodowymi w zakresie przewidzianym prawem (konsultacje, opinie, uzgodnienia - ZFŚS);

- praca rodziców na rzecz szkoły;

- udział w konkursach, imprezach pozaszkolnych w mieście, gminie, powiecie, województwie, kraju;

- współudział w organizowaniu imprez dla dzieci i młodzieży;

Integracji szkoły ze środowiskiem służyć będą działania promocyjne w formie:

- organizowania imprez, festynów dla mieszkańców miasta,

- informowania o osiągnięciach szkoły organu prowadzącego i nadzorującego,

- publikacji w prasie lokalnej na temat działalności szkoły;

- korzystanie z możliwości telewizji kablowej;

- promowania szkoły i osiągnięć nauczycieli na stronach internetowych szkoły. Na każdym z poziomów, od fundamentów aż po dach, ważna jest praca, zaangażowanie i fachowość nauczycieli, wychowawców, rodziców. To ona powoduje, że nasz szkolny gmach jest mocny, stabilny i bezpieczny.

Tytułowy planowy rozwój ucznia nie ma szans zaistnieć bez planowego rozwoju nauczyciela i wychowawcy. Nauczyciele i wychowawcy naszej szkoły zrozumieli to już dawno. Największy wskaźnik nauczycieli dyplomowanych we wszystkich szkołach Gminy Miejskich (w Nowej Soli - aż 29). Wszyscy nauczyciele w szkole mają min. dwa kierunki nauczania. Wspomagam ich w spełnieniu wymagań w zakresie jakości pracy poprzez:

— zapewnienie szkoleń i warsztatów w ramach wewnątrzszkolnego doskonalenia zawodowego nauczycieli zgodnie z potrzebami i oczekiwaniami nauczycieli,

- dostarczenie bieżącej informacji o możliwościach doskonalenia zewnętrznego,

- dofinansowanie doskonalenia zewnętrznego - w ramach posiadanych środków finansowych i zgodnie z potrzebami szkoły,

- instruktaż i doradztwo,

- organizowanie debat (dyskusji) z udziałem rodziców, uczniów, władz lokalnych z przedstawicielami instytucji działającymi na rzecz edukacji,

- tworzenie warunków do wymiany doświadczeń pomiędzy szkołami. 


\section{Uwagi końcowe}

Szeroka problematyka kierowania szkołą obejmuje kompetencje organizacyjne, pedagogiczne, psychologiczne i prawne oraz dostrzeganie tendencji w unowocześnianiu systemu edukacyjnego, dlatego wymaga od dyrektora twórczego działania i podnoszenia ciągle swoich kompetencji.

Działam więc, by sprostać potrzebom i oczekiwaniom środowiska szkoły. Do tego jednak potrzebne jest zaangażowanie całego zespołu. Szkołę traktuję jako szczególną instytucję publiczną, wspólnotę nauczycieli, uczniów, rodziców uzależnioną w różny sposób od jej funkcjonowania. Zarządzam szkołą kierując się następującymi zasadami:

- bogacić swoją wiedzę;

- stosować demokratyczny styl zarządzania;

- delegować uprawnienia;

- zarządzać poprzez jakość.

\section{Efekty pracy:}

Publiczna Sześcioletnia Szkoła Podstawowa nr 6 w Nowej Soli to szkoła, która:

- dobrze uczy każdego,

- sprawiedliwie ocenia,

- uczy myśleć i rozumieć świat,

- rozwija społecznie,

- uczy wrażliwości,

- pomaga uwierzyć w siebie,

- przygotowuje do przyszłości.

\section{Bibliografia}

Bratkowski T., 1979: Kształtowanie i ochrona środowiska. PWN, Warszawa.

Cichy D. 1996: Program edukacji środowiskowej. Teoria i praktyka. NFOŚiGW, Warszawa Skierniewice.

Czaja Z., Bajon P., 2001: Alternatywna edukacja ekologiczna - ogólne założenia. W: Edukacja ekologiczna na progu XXI wieku. Stan. Możliwości. Programy, Warszawa, Verbinum, Wydawnictwo Księży Werbistów.

Dylak S., 1997: (red.) Przyrodnicze rozumowanie najmłodszych, czyli jak uczyć inaczej, Wyd. Fot. Art., Rzeszów.

Hanisz J., 1998: Zintegrowana edukacja wczesnoszkolna. WSiP, Warszawa.

Jarzyńska I., 2004: Cele i zadania nauczania treści przyrodniczych zintegrowanej edukacji wczesnoszkolnej w opinii nauczycieli. W: „Efekty edukacji przyrodniczej, biologicznej i środowiskowej w zreformowanej szkole" Red. Kowalski R., Wydawnictwo Akademii Podlaskiej, Siedlce.

Kąkol J., 2002: Edukacja EKO-logiczna w szkole podstawowej. WSiP, Warszawa. 
Międzynarodowa Strategia Edukacji Środowiskowej. 1990, tłum. Olaczek R., LOP, Warszawa. Okoń W., 1987: Wprowadzenie do dydaktyki ogólnej, Warszawa.

Pęczkowski R., 1998: Poziom osiągnięć szkolnych uczniów klasy III z przedmiotu : „Środowisko społeczno-przyrodnicze". W: Dziecko w świecie przyrody i nauki. Red. Solomon J., Dylak S., Wydawnictwo Edytor w Toruniu \& WSN w Warszawie, Toruń - Warszawa.

Sawicki M., 1997: Edukacja środowiskowa w klasach I - III szkoły podstawowej. Warszawa, Wydawnictwo Naukowe Semper.

Zioło I., 2002: Edukacja środowiskowa na poziomie nauczania zintegrowanego. WN AP, Kraków.

\title{
„Education for balanced development in integrated primary school"
}

\begin{abstract}
SUMMARY
The importance of edutacion for balanced development in primary school is really vital. School is one of the institutions which must supply its students with certain knowledge about the natural environment, teach them responsibility towards the natural environment and thmeselves, make them aware of the dangers created by modern civilization and teach, how to use the natural resources in proper way.
\end{abstract}

